\title{
Reiter haemagglutination test: a screening test for syphilis
}

\author{
A A AL-QUDAH AND ANN MOSTRATOS \\ From the Department of Bacteriology and Virology, University of Manchester Medical School, \\ Manchester
}

SUMMARY Using an ultrasonicate of the Reiter treponeme as antigen the Reiter haemagglutination test (RHA) was evaluated as a serological test for syphilis. Comparison of the results of the cardiolipin Wassermann reaction, Reiter protein complement-fixation test, the fluorescent treponemal antibody-absurbed (FTA-ABS) test, the Treponema pallidum haemagglutination test (TPHA) (at dilutions of $1 / 16$ and 1/80), and the Venereal Disease Research Laboratory test with those of the RHA showed that the RHA was sensitive $(85 \cdot 8 \%)$ and agreed well $(85 \cdot 8 \%)$ with the FTA-ABS test result. Simplicity, sensitivity, availability of the antigen, and the very low cost of this test support its use as a first-line screening test for syphilis.

\section{Introduction}

The changes that have recently taken place in the serology of syphilis have fortunately tended to make the subject less complicated and more rational than it was in the past. The routine diagnosis of syphilis is still hampered, however, by the inability of investigators to culture Treponema pallidum in vitro. Furthermore, the cutaneous manifestations of primary and secondary syphilis are inconstant. In some patients, the first warning of the disease is the appearance of tertiary lesions. Since those of late syphilis may be irreversible, it is important to recognise the disease early. ${ }^{1}$ To achieve this we must rely mainly on serological methods to detect antibodies in the patient's serum or cerebrospinal fluid.

Infection with $T$ pallidum results in the production of several distinct types of antibodies, those directed against treponemal antigens, which may be specific and group-specific, and those directed against lipoidal antigens, which are non-specific. ${ }^{2}$

New methods of identifying $T$ pallidum, as well as serological tests and modifications of standard tests, continue to be developed. Consequently a large number of tests using treponemal or lipoidal antigens have been developed, but the usefulness of many of these procedures needs confirmation. ${ }^{3}$

Of the newer methods the $T$ pallidum haemagglutination (TPHA) test has been evaluated

Address for reprints: Dr A Mostratos, Department of Bacteriology and Virology, University of Manchester Medical School, Oxford Road, Manchester M13 9PT

Accepted for publication 5 April 1982 widely ${ }^{2}$ 4-14 and represents an important development in the field.

The simplicity and reproducibility of the test have been accepted by almost all workers in the field. In principle, the test is very attractive, but the difficulties encountered in growing pathogenic treponemes in rabbit testicles, the time and labour needed, and the consequent high cost of the antigen make the commercially available TPHA kit unsuitable for many routine serological laboratories. We investigated the possibility of coating the red cells for the haemagglutination test with material derived from the Reiter treponeme, which is readily cultivated in the laboratory.

\section{Materials and methods}

\section{SERA}

Of 208 selected sera, 113 were from patients who attended the special treatment clinic, Manchester Royal Infirmary, and were diagnosed clinically and serologically as having syphilis, and 95 were from presumed healthy persons. Before testing each sample was inactivated by heat at $56^{\circ} \mathrm{C}$ for 30 minutes.

\section{ANTIGEN}

Reiter treponemes (seeding cultures received from Wellcome Company) were grown on Christiansen's ${ }^{15}$ modification of Brewer's thioglycollate medium with the omission of agar and resazurin: trypticase $15 \mathrm{~g}$, 
sodium chloride (analar) $2.5 \mathrm{~g}$, D-glucose $5.0 \mathrm{~g}$, yeast extract (Difco) $5.0 \mathrm{~g}$, sodium thioglycollate $0.5 \mathrm{~g}$, L-cysteine $\mathrm{HCl} 0.75 \mathrm{~g}$, and distilled water to make one litre. After the $\mathrm{pH}$ of the medium had been adjusted to $7 \cdot 2$, the medium was autoclaved at $121^{\circ} \mathrm{C}$ for 15 minutes at $15 \mathrm{lb}$, cooled at $37^{\circ} \mathrm{C}$, supplemented with $10 \% \mathrm{v} / \mathrm{v}$ sterilised inactivated calf serum, inoculated with a 5-10\% v/v inoculum, and incubated at $37^{\circ} \mathrm{C}$ for 5-6 days.

After centrifugation the treponemes were washed four times in $0.1 \% \mathrm{w} / \mathrm{v}$ azide saline and resuspended in distilled water to give a density on Browns opacity standards of 3 . The container was immersed in ice and the bacterial suspension sonicated in a Rapidis 300 ultrasonic machine for 10-15 minutes. The preparation was then centrifuged at $500 \times g$ for five minutes or left overnight at $4^{\circ} \mathrm{C}$, after which the supernatant was collected and sodium azide added to a final concentration of $0.1 \% \mathrm{w} / \mathrm{v}$. This cell lysate was divided into $5-10 \mathrm{ml}$ aliquots and kept at $-20^{\circ} \mathrm{C}$ until required. The working dilution of the antigen was determined by sensitising small quantities of formolised tanned red cells with serial dilutions of antigen and testing them with known positive and negative sera in a chess-board titration. Each well of the $U$ microtitre plate contained a mixture of $0.075 \mathrm{ml}$ of serum dilution and $0.075 \mathrm{ml}$ of $0.94 \%$ test or control cells in $1.5 \% \mathrm{w} / \mathrm{v}$ normal rabbit serum. The working dilution of the antigen was the one which allowed maximum differentiation between positive and negative sera and which gave the highest titre with the positive serum; the dilution of antigen used was $1 / 10$.

\section{SENSITISATION OF FOWL RED BLOOD CELLS WITH ANTIGEN}

Fowl erythrocytes (RBC) were formolised by the method described by Sequeira and Eldridge. ${ }^{6}$ The cells were then suspended in saline to a concentration of $3.75 \%$ and mixed with an equal volume of $1 / 8000$ tannic acid solution; the mixture was incubated at $37^{\circ} \mathrm{C}$ for 15 minutes, the cells were then washed twice with saline and resuspended in phosphate-buffered saline (PBS), $\mathrm{pH} 6 \cdot 4$, to their original concentration $(3 \cdot 75 \%)$. To one volume of cells diluted in four volumes of PBS one volume of a $1 / 10$ dilution of the antigen in PBS was added. The mixture was incubated for 30 minutes at $37^{\circ} \mathrm{C}$ with occasional shaking. These were termed the test cells. Simultaneously another volume of RBCs was treated exactly as the test cells except that the antigen was replaced by PBS; these were termed the control cells. Test and control cell suspensions were centrifuged at $1000 \times g$ for 4-5 minutes, washed once with saline, and resuspended in two volumes of $1.5 \% \mathrm{v} / \mathrm{v}$ rabbit serum in saline (at a final concentration of $1 \cdot 875 \%$ ).

\section{RHA TEST PROCEDURE}

For each inactivated serum specimen three wells of a $\bar{\sigma}$ $\mathrm{U}$ microtitration plate were filled with serum diluted in PBS (pH 7.2) to final dilutions of $1 / 4,1 / 16$ and $\vec{F}$ 1/16. Using a standard $0.025-\mathrm{ml}$ dropper, one drop $\stackrel{\text { SO }}{\rightarrow}$ of test cells was added to well number 2 and one drop of control cells to well number 3 . The plate was $\frac{\bar{c}}{\bar{m}}$ covered, shaken for 30 seconds, and incubated at $\frac{\sigma}{\vec{D}}$ $37^{\circ} \mathrm{C}$ for $45-60$ minutes. Positive and negative $\unrhd$ control sera were included in each group of samples $\stackrel{\infty}{\%}$ tested and were treated exactly as the sera under test.

\section{Reading of results}

Results were read and recorded as follows: strongly positive, smooth carpet of agglutinated cells on the well surface; positive, smooth carpet of agglutinated cells surrounded by irregular margin of cells; and or negative, button or definite ring of cells. Where it $\stackrel{N}{\infty}$ was difficult to decide whether a sample was positive or negative, the serum was retested at a 1/8 dilution. Serum samples with which control cells did not give a button were absorbed by the addition of $0.1 \mathrm{ml}$ serum to $0.3 \mathrm{ml}$ control cell suspension in a small plastic tube. After incubation at $37^{\circ} \mathrm{C}$ for 30 minutes the mixture was centrifuged and the supernate used as a 1/4 dilution of the original serum sample. Further test dilutions were made and tested again. If the control cells again did not settle to a button, the test was reported as "no valid result."

\section{OTHER TESTS}

Different conventional serological tests for syphilis were carried out on the same serum samples. Cardiolipin Wasserman reaction (CWR) and Venereal Disease Research Laboratory slide test (VDRL) to detect antilipoidal antibodies, Reiter protein complement-fixation (RPCFT) test to detect group antitreponemal immunoglobulin, $T$ pallidum haemagglutination test (TPHA) (at 1/80 and 1/16 serum dilutions) and the fluorescent treponemal antibody-absorbed (FTA-ABS) test to detect the specific antitreponemal antibodies were performed. Most of the reagents were obtained from Wellcome Company and the techniques followed were according to the recommendations of the manufacturers; the FTAABS test was performed according to the procedure described by Wilkinson. ${ }^{16}$

\section{Results}

Several serological tests were performed on the same serum specimens. For VDRL tests sera were used undiluted; for the CWR, the RPCFT, and the FTAABS test sera were diluted to 1/5; for the TPHA sera were diluted to $1 / 80$ and $1 / 16$ and for the RHA test to $1 / 16$. 
The results are summarised in table I. The FTAABS test was performed twice independently. The RHA test result was positive in sera from 23 patients who did not have syphilis; in sera from this group of non-infected patients the VDRL and TPHA (at a $1 / 16$ dilution) test results were positive in 16 and 15 patients respectively. The results of the testing of sera from patients with syphilis are shown in the figure.

The percentage sensitivities of each test in the different stages of syphilis and in treated and untreated patients are shown in table II. Both tables show clearly that in all stages of syphilis, both treated and untreated, the results of the TPHA $(1 / 16)$ and the RHA tests were nearest to those of the FTA-ABS test.

The results of screening with different combinations of two tests are shown in table III. The total number of sera in which either one or both tests gave positive results was compared with the FTAABS test results on the same serum samples. From this, truly positive and false-positive results were calculated while false-negative results were determined by subtraction of the number of true positives from 113, which was the number of confirmed positives. The RPCFT and RHA test

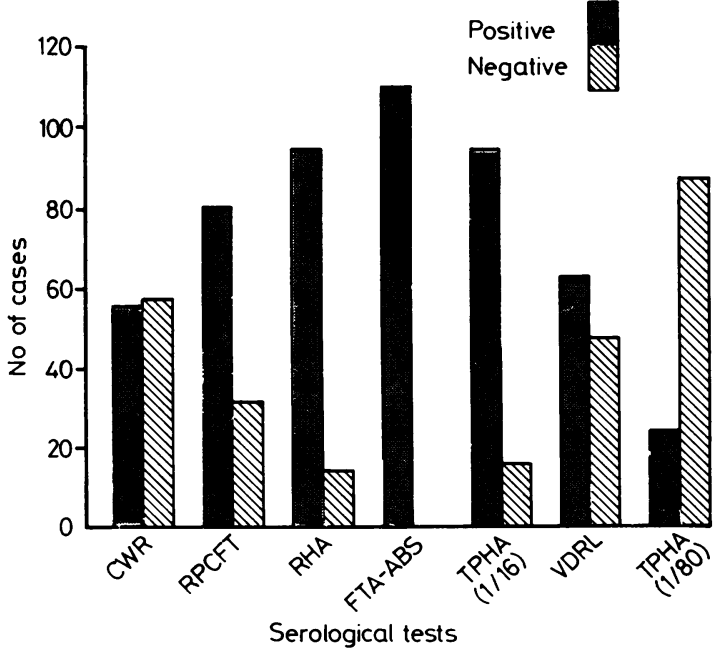

FIGURE Results of different serological tests on 113 sera from patients with syphilis $(C W R=$ cardiolipin Wassermann reaction; $R P C F T=$ Reiter haemagglutination assay; FTA-ABS = fluorescent treponemal antibodyabsorbed (test); TPHA = T pallidum haemagglutination assay).

TABLE I Results of different serological tests for syphilis on 208 human (113 syphilitic and 95 non-syphilitic) sera

\begin{tabular}{|c|c|c|c|c|c|}
\hline \multirow[b]{2}{*}{ Test } & \multicolumn{3}{|c|}{ Syphilitic sera } & \multicolumn{2}{|c|}{ Non-syphilitic sera } \\
\hline & No positive & No negative & $\begin{array}{l}\% \text { Agreement with } \\
F T A-A B S \text { (sensitivity) }\end{array}$ & No positive & $\%$ False-positive \\
\hline CWR & 56 & 57 & $49 \cdot 6$ & 3 & $3 \cdot 2$ \\
\hline RPCFT & 81 & 32 & $71 \cdot 7$ & 6 & $6 \cdot 3$ \\
\hline RHA & 97 & 16 & $85 \cdot 8$ & 23 & $24 \cdot 2$ \\
\hline FTA-ABS & 113 & 0 & $100 \cdot 0$ & 0 & 0 \\
\hline TPHA $(1 / 16)$ & 97 & 16 & $85 \cdot 8$ & 15 & $15 \cdot 8$ \\
\hline VDRL & 65 & 48 & $57 \cdot 5$ & 16 & $16 \cdot 8$ \\
\hline TPHA $(1 / 80)$ & 24 & 89 & $21 \cdot 2$ & 2 & $2 \cdot 1$ \\
\hline
\end{tabular}

CWR = cardiolipin Wassermann reaction; RPCFT = Reiter protein complement-fixation (test); RHA = Reiter haemagglutination (test); FTA $\mathrm{ABS}=$ fluorescent treponemal antibody-absorbed (test); TPHA $=T$ pallidum haemagglutination assay; VDRL = Venereal Disease Research Laboratory (test)

TABLE II Comparison of sensitivity of CWR, FTA-ABS, RPCFT, TPHA (1/80), TPHA (1/16), RHA, and VDRL tests* in 113 sera from treated and untreated patients at different stages of syphilis

\begin{tabular}{|c|c|c|c|c|c|c|c|c|c|}
\hline \multirow[b]{2}{*}{ Stage of syphilis } & \multirow[b]{2}{*}{ Treatment } & \multirow[b]{2}{*}{ No of cases } & \multicolumn{4}{|c|}{$\%$ Sensitivity } & \multirow[b]{2}{*}{$\begin{array}{l}\text { TPHA } \\
(I / 80)\end{array}$} & \multirow[b]{2}{*}{$\begin{array}{l}\text { TPHA } \\
(1 / 16)\end{array}$} & \multirow[b]{2}{*}{$R H A$} \\
\hline & & & $C W R$ & $F T A-A B S$ & $R P C F T$ & $V D R L$ & & & \\
\hline \multirow{2}{*}{ Primary } & Treated & 12 & $41 \cdot 7$ & 100 & $58 \cdot 3$ & $25 \cdot 0$ & $16 \cdot 7$ & $83 \cdot 3$ & $83 \cdot 3$ \\
\hline & Untreated & 4 & $75 \cdot 0$ & 100 & $75 \cdot 0$ & $75 \cdot 0$ & $00 \cdot 0$ & $50 \cdot 0$ & $75 \cdot 0$ \\
\hline \multirow{2}{*}{ Secondary } & Treated & 22 & $50 \cdot 0$ & 100 & $81 \cdot 8$ & $63 \cdot 6$ & $22 \cdot 7$ & $90 \cdot 9$ & $81 \cdot 8$ \\
\hline & Untreated & 3 & $100 \cdot 0$ & 100 & $100 \cdot 0$ & $100 \cdot 0$ & $66 \cdot 6$ & $100 \cdot 0$ & $100 \cdot 0$ \\
\hline \multirow{2}{*}{$\begin{array}{l}\text { Latent } \\
\text { Congenital }\end{array}$} & Treated & 39 & $51 \cdot 3$ & 100 & $69 \cdot 2$ & $69 \cdot 2$ & $28 \cdot 2$ & $84 \cdot 6$ & $82 \cdot 0$ \\
\hline & Treated & 8 & $25 \cdot 0$ & 100 & $50 \cdot 0$ & $25 \cdot 0$ & $00 \cdot 0$ & $75 \cdot 0$ & $75 \cdot 0$ \\
\hline \multirow{2}{*}{ Stage not specified } & Treated & 14 & $42 \cdot 9$ & 100 & $71 \cdot 4$ & $35 \cdot 7$ & $14 \cdot 3$ & $92 \cdot 9$ & $100 \cdot 0$ \\
\hline & Untreated & 11 & $45 \cdot 5$ & 100 & $81 \cdot 8$ & $72 \cdot 7$ & $18 \cdot 2$ & $90 \cdot 9$ & $100 \cdot 0$ \\
\hline \multirow{2}{*}{ Total } & Treated & 95 & $46 \cdot 3$ & 100 & $69 \cdot 5$ & $53 \cdot 7$ & $21 \cdot 0$ & $86 \cdot 3$ & $84 \cdot 2$ \\
\hline & Untreated & 18 & $61 \cdot 1$ & 100 & $83 \cdot 3$ & $77 \cdot 8$ & $22 \cdot 2$ & $83 \cdot 3$ & $94 \cdot 4$ \\
\hline
\end{tabular}

* For meaning of abbreviations see table I 
TABLE III Results of screening with different combinations of two tests in 208 selected human (113 syphilitic and 95 nonsyphilitic) sera

\begin{tabular}{|c|c|c|c|c|c|c|c|c|c|c|c|c|}
\hline Type of results & $\begin{array}{l}C W R / \\
R P C F T\end{array}$ & $\begin{array}{l}\text { RPCFT/ } \\
T P H A \\
(1 / 80)\end{array}$ & $\begin{array}{l}\text { RPCFT/ } \\
\text { TPHA } \\
(1 / 16)\end{array}$ & $\begin{array}{l}\text { RHA/ } \\
R P C F T\end{array}$ & $\begin{array}{l}\text { VDRL/ } \\
R P C F T\end{array}$ & $\begin{array}{l}C W R / \\
V D R L\end{array}$ & $\begin{array}{l}C W R / \\
T P H A \\
(I / 80)\end{array}$ & $\begin{array}{l}C W R / \\
T P H A \\
(1 / 16)\end{array}$ & $\begin{array}{l}C W R / \\
R H A\end{array}$ & $\begin{array}{l}V D R L / \\
T P H A \\
(1 / 80)\end{array}$ & $\begin{array}{l}V D R L / \\
T P H A \\
(I / 16)\end{array}$ & $\begin{array}{l}\text { VDRL/ } \\
R H A\end{array}$ \\
\hline
\end{tabular}

*Either one or both test results were positive

For meaning of abbreviations see table I

combined detected 104 truly positive sera, but there were 27 false-positive and nine false-negative results. The RHA and CWR combined detected 103 truly positive, 24 false-positive, and 10 false-negative results, while the RPCFT and TPHA $(1 / 16)$ combined detected 103 positive but 17 false-positive and 10 false-negative results.

\section{Discussion}

In this series the sensitivities of the CWR, RPCFT, FTA-ABS, and VDRL tests were similar to those reported by other workers, but the most unexpected results were found with the TPHA $(1 / 80)$ test, an overall sensitivity of $21 \cdot 2 \%$. Compared with the FTA-ABS test, the TPHA $(1 / 80)$ has been shown to be highly sensitive by Garner and co-workers ${ }^{17}$ $(97 \%)$, Johnston ${ }^{5}(97 \cdot 8 \%)$, Young et al al $^{7}(96 \cdot 1 \%)$, Le Clair ${ }^{4}(92 \cdot 3 \%)$, and Luger et al ${ }^{18}$ (nearly $100 \%$ ). These workers used the kit from the Fujizoki Company of Japan. Blum et al ${ }^{19}$ used a kit supplied by Canalco Inc, Rockville, Md, USA, based on the method of Tomizawa and Kasamatsu, ${ }^{20}$ and found agreement of $90.2 \%$ between the FTA-ABS and TPHA tests; they were disappointed by the falsepositive and false-negative rates and questioned the reliability of the TPHA. Later work by Garner et $a^{21}$ on "problem sera" led them to be less enthusiastic than before. MacFarlane and Elias-Jones ${ }^{9}$ compared Wellcome and Fujizoki kits at 1/80 serum dilutions and found that the former lacked sensitivity. Using a 1/40 serum dilution the Wellcome kit gave improved sensitivity, but both kits gave a high false-positive rate. Using the Fujizoki reagents Alessi and Scioccati ${ }^{10}$ found that the percentage sensitivity decreased with increasing serum dilution from $91 \cdot 1 \%$ at $1 / 20$ to $74 \cdot 4 \%$ at $1 / 80$. The use of a macromethod improved sensitivity to $91.6 \%$ at $1 / 80 .{ }^{10}$ All other workers have used the microtechnique.

Thus, materials for the TPHA test are not always of comparable quality, and this probably explains our low sensitivity rate with the TPHA test at a serum dilution of $1 / 80$. Since the Reiter treponeme and $T$ pallidum possess common antigens the TPHA test will detect both group-specific and $T$ pallidumspecific antibodies unless the group antibodies are absorbed out completely. Except in early infection group antibody activity may equal or even exceed that of the specific antibodies. ${ }^{22} \mathrm{~A}$ high serum dilution may result in failure to detect specific antibodies. At a low serum dilution both types of antibody may be present. Using sera diluted $1 / 80$ in the TPHA some positive sera may not be identified; at a lower serum dilution mainly group antibody is detectable.

If the haemagglutination test is detecting group antibody there should be no need to use the expensive $T$ pallidum antigen, which can be replaced with Reiter treponeme antigen. The RHA test showed an $85.8 \%$ agreement with the FTA-ABS test (and 100\% agreement with the Wellcome TPHA). The falsepositive rate for the RHA test $(24 \cdot 2 \%)$ was high but the false-negative rate $(14 \cdot 2 \%)$ compared very favourably with that of the CWR, RPCFT, and VDRL test. The combination of two tests giving the highest rate of truly positive results and least falsenegative results was the RHA test and the RPCFT. If the TPHA is used as a screening test only, or if good quality reagents are not available, then it might be more economic to use the RHA test instead. In any case the RHA is a screening test that misses fewer cases than the other screening tests at present in use.

We are grateful for the co-operation of the staff of the special treatment clinic, Manchester Royal Infirmary, especially $\operatorname{Dr} \mathbf{N} A$ Durham, $M r ~ R$ Speakman, and Mrs J I Bunner, who provided us with the serum specimens. We also thank Mr D Coupes and Mrs C Bradburn for their kind help.

\section{References}

1. Sommers HM. The Biologic and Clinical Basis of Infectious Diseases. 2nd ed. London: WB Saunders Company, 1980: 482-500.

2. O'Neil P. A new look at the serology of treponemal diseases. Br J Vener Dis 1976;52:296-9.

\section{.}


3. Notowicz A, Menke HE. In: Recent Advances in Sexually Transmitted Diseases. Harris JRW, ed. London: Churchill Livingstone, 1981:93-100.

4. Le Clair RA. Evaluation of a qualitative haemagglutination test for antibodies to Treponema pallidum. J Infect Dis 1971; 123:668-70.

5. Johnston NA. Treponema pallidum haemagglutination test for syphilis: evaluation of a modified micromethod. Br J Vener Dis 1972;48:474-9.

6. Sequeira PJL, Eldridge AG. Treponemal haemagglutination test. Br J Vener Dis 1973;49:242-8.

7. Young $\mathrm{H}$, Henrichsen $\mathrm{C}$, Robertson DHH. Treponema pallidum haemagglutination test as a screening procedure for the diagnosis of syphilis. Br J Vener Dis 1974;50:341-6.

8. Robertson DHH, McMillan A, Young H, Henrichsen C. Clinical value of the Treponema pallidum haemagglutination test. Br J Vener Dis 1976; 51:79-82.

9. MacFarlane DE, Elias-Jones TF. Screening tests for syphilis. A comparison of the Treponema pallidum haemagglutination assay with two automated serological tests. Br J Vener Dis 1977; 53:348-52.

10. Alessi E, Scioccati L. TPHA test experience at the clinic of dermatology, University of Milan. Br J Vener Dis 1978; 54:151-4.

11. Birry A, Kasatiya S. Evaluation of microhaemagglutination assay to determine treponemal antibodies in CSF. Br J Vener Dis 1979; 55:239-44.

12. Kasatiya A, Birry A. Further evaluation of the micro-haemagglutination test to determine treponemal antibodies in CSF. $B r$ JVener Dis 1980;56: 77-80.

13. Young H, Hunter JM. Quantitative microhaemagglutination assay for Treponema pallidum antibodies in humans. $\mathrm{Br} J$ Vener Dis 1981;57:147.
14. Luger A, Schmidt BL, Spendlingwimmer I, Steyrer $K$. Specificity of the Treponema pallidum haemagglutination test. Analysis of results. Br J Vener Dis 1981;57:178-80.

15. Christiansen AH. The Reiter strain of Treponema pallidum, origin, cultivation and use in immunization of rabbits. Acta Pathol Microbiol Scand 1963;57:81-6.

16. Wilkinson AE. Serological tests for syphilis. In: Laboratory Diagnosis of Venereal Diseases. Public Health Laboratory Service Monograph series No 1. London: HMSO, 1972;1-24.

17. Garner MF, Backhouse JL, Daskalopoulos G, Walsh JL. Treponema pallidum haemagglutination test for syphilis. Comparison with the TPI and FTA-ABS tests. Br J Vener Dis 1972; 48:470-9.

18. Luger A, Schmidt BL, Spendlingwimmer I, Steyrer $K$. Specificity of the Treponema pallidum haemagglutination test. Analysis of results. Br J Vener Dis 1981;57:178-80.

19. Blum G, Ellner PD, McCarthy LR, Papachristos T. Reliability of the treponemal haemagglutination test for serodiagnosis of syphilis. $J$ Infect Dis 1973;127:321-4.

20. Tomizawa T, Kasamatsu S, Yamaya S. Usefulness of the haemagglutination test using Treponema pallidum antigen (TPHA) for the serodiagnosis of syphilis. Japan J Med Sci Biol 1969; 22:341-50.

21. Garner MF, Backhouse JL, Daskolopoulos G, Walsh JL. The Treponema pallidum haemagglutination (TPHA) test in biological false positive and leprosy sera. J Clin Pathol $1973 ; 26: 258-60$.

22. Wilkinson AE, Rayner CFA. Studies on the fluorescent treponemal antibody (FTA) test. Br J Vener Dis 1966; 42: 8-15. 